\title{
Perjuangan Hidup Mahasiswa Pekerja Di Pasar Mardika Kota Ambon Terhadap Prestasi Belajar
}

\author{
La Basri $^{1}$, Siti Nurul Nikmatul Ula ${ }^{2}$ \\ Program Studi Sosiologi, FISIP, Universitas Muhammadiyah Sorong, Indonesia \\ Korespondensi*: basrila90@gmail.com
}

\begin{abstract}
ABSTRAK
Pasar Mardika menunjukan bahwa adanya keterkaitan antara mahasiswa dan pasar tersebut, dimana mahasiswa yang kuliah di perguruan tinggi di Propinsi Maluku terlebih khusus di kota Ambon banyak yang menggantungkan hidupnya di pasar karena kurangnya ekonomi. Ada diantara mereka yang datang dari jauh yang kuliahnya ditempat tertentu dan kebanyakan dari mereka adalah orang-orang yang kurang mampuh dalam kondisi ekonomi sehingga mereka lebih memilih kuliah sambil bekerja untuk mencukupi kebutuhan hidup sehari-hari, ada kemungkinan akan berpengaruh pada prestasi belajar yang mereka peroleh ketika berada di kampus. Tujuan dalam penelitian ini untuk mengetahui kondisi sosial, etika usaha dan perkembangan prestasi belajar para mahasiswa. Metode yang digunakan dalam penelitian ini adalah metode diskriptif analisis kualitatif, yaitu dengan cara penggambaran atas seluruh rangkayan kegiatan penelitian sejak dari tahap proses pencarian data, analisa data, dan penarikan kesimpulan. Prestasi yang diperoleh mahasiswa sebagian besar sangatlah baik yang berkaitan dengan proses pembelajaran baik di kampus maupun di pasar.
\end{abstract}

Kata Kunci: Perjuangan Hidup, Mahasiswa Pekerja, Prestasi Belajar

\begin{abstract}
Mardika Market shows that there is a relationship between students and the market, where students who study at universities in Maluku Province, especially in Ambon, often depend on the market for lack of economy. There are those who come from remote areas who study in certain places, and most of them are people who are less capable in economic conditions, so they prefer to study while working to meet the needs of daily life. There is a possibility that will affect their learning achievements on campus. The purpose of this study is to determine the social conditions, business ethics and the development of student achievements. The method used in this research is descriptive qualitative analysis method, which is by describing the entire range of research activities from the stage of the process of searching data, analyzing data, and drawing conclusions. Most of the achievements obtained by students are very well related to the learning process both on campus and in the market.
\end{abstract}

Keywords: Life Struggle, Student Workers, Learning Achievements

50 Mahasiswa Pekerja dan Prestasi Belajar.... 


\section{PENDAHULUAN}

Secara sosiologis, mahasiswa cenderung diperhadapkan dengan adanya perubahan-perubahan sosial yang begitu kompleks, baik menyangkut tatanan masyarakat, pertumbuhan penduduk, perubahan lingkungan, lapangan pekerjaan, dan sebagainya. Semua realitas sosial itu dalam sosiologi selalu didekati dari berbagai perspektif, seperti perspektif fungsionalisme,fenomenologis,rasionalism e, dan idealisme. Para sosiologi seperti Karl Marx akan menyoroti dari perpektif struktur social yang di determinasi oleh dualisme atau pertentangan kelas untuk menguasai dalam kehidupan manusia. Sementara penganut fenomenologis, seperti Alfred Schulter akan mendekati dari gejala-gejala atau fenomena-fenomena social yang mempengaruhi kehidupan masyarakat, semantara pengamat fungsionalisme seperti Talkot Parson akan menyoroti dari perpektif peranan atau fungsi masyarakat. Max Weber dari sisilain menyoroti bentukbentuk kesadaran rasional dalam bertindak. Sehingga Max Weber meletakkan adanya sebuah tatanan etika sosial yang berbasis tindakan rasional, seperti pertimbanganpertimbangan dalam berbagai kehidupan sosial atau dasar, rasio, kerja keras, disiplin dan hemat untuk membangun keberlanjutan hidup secara lebih tertib menuju taraf kesejahtraan yang luas. Sehingga Mahasiswa mampu untuk menentukan pilihanya berdasarkan kemampuan yangdimilikinya baik di kampus maupun ketika berada di pasar.

Era globalisasi merupakan tantangan tersendiri bagi Perguruan Tinggi dalam menyiapkan lulusannya agar mampu berkompetisi dalam memperebutkan pasar kerja dan menghasilkan lulusan yang inovatif dan kreatif. Universitas sebagai teranportasi nilai dalam menciptakan lulusannya di masyarakat terhadap tingkat kebutuhan permintaan pasar untuk memenuhi sumberdaya yang diperlukan oleh dunia usaha atau pasar gelobal. Namun, perguruan tinggi kurang cepat menanggapi tuntutan persyaratan baru dunia kerja terhadap kemampuan, ketrampilan, dan sikap para lulusan di sektor modern. Berbagai kekurangan dikeluhkan, seperti: dasar pengetahuan yang kurang memadai, belum siap kerja, kurang produktif, kurang dapat bekerjasama dalam tim, dan sebagainya. Ada juga perguruan tinggi kurang antisipatif terhadap perkembangan besar yang akan dihadapi di masa depan dengan globalisasi dan pasar bebas Asia Pasifik. Sesuai dengan kondisi yang demikian maka 
setiap perguruan tinggi baik swasta maupun negeri perlu memperhatikan seberapa besar tingkat pengetahuan dan keterampilan yang dimiliki mahasiswa sehingga nantinya dapat diperoleh lulusan yang baik dengan cara meningkatkan sistem pendidikan yang berkualitas bagi mahasiswanya.

Sistem pendidikan yang berkualitas dimaksud adalah proses belajar mengajar secara formal di lembaga pendidikan khususnya perguruan tinggi. Adapun pengertian belajar itu sendiri, salah satunya menurut Dalyono (1994:49) belajar adalah suatu usaha atau kegiatan, yang bertujuan mengadakan perubahan di dalam diri seseorang, mencakup perubahan tingkah laku, sikap, kebiasaan, ilmu pengetahuan serta keterampilan dan sebagainya. Belajar adalah kegiatan manusia yang sangat penting dan harus dilakukan selama hidup, karena melalui belajar dapat melakukan perbaikan dalam berbagai hal yang menyangkut kepentingan hidup, dengan kata lain melalui belajar dapat memperbaiki nasib, menggapai cita-cita yang didambakan.

Selain itu tidak dapat dipungkiri bahwa, universitas sebagai tempat transformasi ilmu antara pengajar dan peserta didik turut andil dalam melahirkan kaum intelektual yang mejadi pelakupelaku di dunia kerja. Bahkan suatu universitas akan membangun stigma negatif atau positif di masyarakat melalui para lulusannya. Hal yang diharapkan dari suatu kegiatan perkuliahan antara pengajar dan peserta didik tak lain adalah pemahaman dan prestasi yang memuaskan dari mahasiswa sebagai bentuk dari keberhasilan pengajaran yang dilakukan oleh seorang pengajar. Pemahaman dan prestasi itu secara ril dapat dilihat dari indeks prestasi (IP) yang diperoleh peserta didik pada akhir periode perkuliahan.

Prestasi yang dihasilkan oleh seorang peserta didik dipengaruhi oleh dua faktor utama, yaitu faktor internal dan faktor eksternal. Faktor internal dapat berupa motivasi diri, sifat, kepribadian, prilaku, dan lainnya. Sedangkan faktor eksternalnya dapat berupa metodologi atau cara mengajar dari pengajar/dosen, pergaulan mahasiswa itu sendiri, kondisi sosiologis, psikologis keluarga, lingkungan perkuliahan dan lain sebagainya .

Salah satu lingkungan sosial diantara manusia dan khususnya para mahasiswa dapat belajar dan mengembangkan potensi diri dalam proses yang berbeda adalah salah satunya di pasar. Pasar merupakan tempat perjumpaan (ruang interaksi sosial) antara pembeli dan penjual, dimana barang dan jasa atau produk akan dipertukarkan antara pembeli dan penjual. Ukuran kerelaan 
dalam pertukaran tersebut biasanya akan muncul suatu tingkat harga atas barang dan jasa yang dipertukarkan tersebut (Ehrenberg dan Smith, 2003).

Di pasar mahasiswa akan belajar mengenal dua bentuk pasar, yakni pasar persaingan sempurna dan pasar persaingan tidak sempurna. Pada pasar persaingan sempurna, penjual dan pembeli memiliki pengetahuan yang sempurna tentang harga suatu barang, sehingga tidak ada satupun pihak yang bisa menguasai harga. Barang yang sama pada pasar persaingan sempurna dijual oleh banyak penjual dengan harga yang sama. Sedangkan pada pasar persaingan tidak sempurna, terdapat satu atau beberapa pihak penjual atau pembeli yang dapat menguasai harga.

Jika diperhatikan fenomena sosial mahasiswa di Maluku khususnya di Kota Ambon, banyak orang-orang yang datang dari jauh, bahkan ada yang datang dari luar Propinsi Maluku tujuan mereka hanya menuntut ilmu bukan untuk bekerja. Namun, dengan kebutuhan ekonomi yang semakin meningkat dan mendesak apalagi bagi mereka yang hidup dengan kos-kosan yang hanya mengharapkan keriman atau bantuan dari orang tua tentu memerlukan biaya yang lebih untuk mencukupi kebutuhanya. Mereka lebih mimilih bekerja ketimbang bersekolah atau kuliah yang akibatnya kuliah mereka terasa terganggu, yang biasanya orang yang kuliah di perguruan tinggi hanya empat sampai lima tahun saja dengan mereka bekerja bisah saja menjadi enam sampai delapan tahun baru mendapatkan gelar sarjana bahkan ada yang di “ Drop Out” dari perguruan tinggi karena faktor ekonomi atau kurang aktif mengikuti kuliah.

Dari beberapa mahasiswa yang berhasil ditemukan di Pasar Mardika Ambon, ada sebagian orang yang kuliah dari angkatan 2005 sampai sekarang 2012 belum wisuda atau belum mendapatkan gelar sarjana karena ia harus mencukupi kebutuhan hidupnya dan para adiknya yang bersekolah. Dari permasalahan di atas dapat digambarkan latar belakang masalah adalah sebagai berikut:Ada sebanyak 76 orang mahasiswa dari barbagai perguruan tinggi di kota ambon yang sedang bekerja di pasar mardika; (1) Pekerjaan yang di lakukan terdiri dari jenis pekerjaan senagai berikut; (a) Penjualan sembako; (b) Penjualan ikan; (c) Penjualan pakayan jadi; (d) Penjualan sayur mayur; (e) Bekerja sebagai karyawan di toko atau pencuci pakayan dan pembersih took.; (2) Curahan jam kerja, 9 jam perhari yang di mulai dari pukul 09.00-18.30 wit. Ada juga yang bekerja dari pukul 18.0020.00 wit. Dengan curahan jam kerja 5 jam perhari.; (3) Lokasi pekerjaan disekitar pasar mardika yang bertempat dalam

53 Mahasiswa Pekerja dan Prestasi Belajar.... 
terminal, depan pertokoan sebagai pedagang kakilima, penjual ikan dan sayur mayur di sekitar pasar arumbae.; (4) Banyak di antara mereka yang bekerja di pasar mardika bermukim di batu merah, soabali, stain, galunggung, kebun cengkeh, tantui dan sekitar pulau ambon lainya. Kebanyakan dari mereka yang tinggal dengan rumah kos-kosan, kontrak rumah serta tinggal sama majikan.; (5) Curahan waktu belajar sangat terbatas karena lebih banyak untuk bekerja di pasar.; (6) Di duga bahwa hal tersebut menambah dampak yang kurang baik terhadap kualitas dan hasil belajar di perguruan tinggi.

\section{METODE}

Penelitian ini berusaha untuk menggambarkan tentang peranan Mahasiswa Pekerja di Pasar Mardika Terhadap Prestasi Belajar dengan melihat permasalahanpermasalahan yang terjadi dalam dunia pendidikan khususnya perguruan tinggi yang semakin miningkat dan berkembang sehingga memerlukan biaya yang tidak sedikit untuk memenuhi kebutuhan tersebut. Terkait dengan hal tersebut, maka metode yang digunakan dalam penelitian ini adalah metode diskriptif analisis kualitatif, yaitu dengan cara penggambaran atas seluruh rangkayan kegiatan penelitian sejak dari tahap proses pencarian data, analisa data, dan penarikan kesimpulan.
Data-data yang dikumpulkan kemudian diproses dalam bentuk yang sederhana, hingga mudah dibaca dan diinterpretasikan. Proses analisis data dalam penelitian ini menggunakan analisis data kualitataf yakni, dengan menghasilkan data diskriptif analisis, apa yang dinyatakan oleh responden baik secara tertulis maupun lisan, selanjutnya dipelajari dan di amati sebagai sesuatu yang utuh. Dengan demikian analisis kualitatif ini memberikan penafsiran terhadap data-data yang ada, setelah datadata terkumpul, kemudian di analisis dan disajikan sesuai variabel-variabel yang dijadikan indikator-indikator dalam penelitian ini, untuk selanjutnya dapat memberikan gambaran yang jelas tentang Mahasiswa Pekerja di Pasar Mardika Terhadap Prestasi Belajar di Perguruan Tinggi.

\section{HASIL DAN PEMBAHASAN}

\section{Mahasiswa Pekerja di Pasar Mardika}

Untuk memiliki kompetensi keilmuan, mahasiswa dituntut untuk bersungguh-sungguh menjalankan tugas utamanya yaitu belajar. Akan tetapi pada kenyataannya ada dari beberapa mahasiswa yang tidak bisa fokus pada tugas utamanya. Hal ini salah satunya dikarenakan adanya peran lain yang harus dilakukan, misalnya bekerja. Menurut Ningsih (2004), alasan yang menyebabkan mahasiswa kuliah 
sambil bekerja dapat digolongkan menjadi dua, yaitu masalah ekonomi dan kemandirian diri. Menurut Syamsi (2000), masalah yang dihadapi oleh mahasiswa dan sikap individu yang bersangkutan akan menentukan pola pengambilan keputusan mahasiswa. Keputusan tersebut dapat diambil, baik berdasarkan intuisi ataupun rasio.

Dalam hal ini mahasiswa punya pendapat tersendiri kenapa mereka harus bekerja disela-sela waktu kuliah yang ada. Seperti yang di katakana oleh salah satu mahasiswa yang bernama La Januri (24 tahun/penjual perlengkapan alat tulis) mengatakan bahwa:Saya bekerja di pasar karena "kebutuhan ekonomi", terutama kebutuhan akan pendidikan yang tiap semester harus dibayar, kebutuhan akan makan dan minum, apalagi saya tinggal dengaan kos-kosan yang suduh tentu menguras waktu untuk bekerja, manah sekarang di perhadapkan dengan tahap penyunan dan seminar proposal.

Selain itu, ada yang berpendapat lain menyangkut dengan mahasiswa pekerja di pasar sebagai mana yang dikatakan oleh Susanti Sampula (22 tahun/penjual bunga hias): Saya bekerja dan tinggal bersama orang (majikan/saudara) itu bukan pilihan saya untuk bekerja, hal ini dikarena pilihan orang tua saya yang tidak mau saya kos selama saya masih kuliah banyak masalah yang terjadi dengan orang atau mahasiswa yang hidup dengan koskosan yang tidak mampu menjaga dirinya terutama para perempuan.

Berdasarkan penjelasan diatas ada dua faktor kenapa Susanti Sampulawa (22 tahun) harus bekerja yaitu pertama punya hubungan saudara dengan majikan, dan kedua adanya kekehawatiran orang tua terhadap anaknya yang tinggal di koskosan.

Menurut La Nawi (25 tahun/penjual pakaian jadi) mengatakan bahwa:Selain menambah pengalaman kerja untuk mengembangkan potensi diri dalam berwirausaha, ada kebutuhan lain yang harus saya penuhi yaitu kebutuhan rumah tangga dan kebutuhan kuliah saya yang harus saya penuhi yaitu istri dan anak.

Begitu pula dengan Yanti Fakaubun (24 tahun/karyawan handphone/HP) mengatakan bahwa: Kebanyakan mahasiswa yang ada di Kota Ambon merupakan pendatang dari berbagai daerah terutama saya dari tenggara, sudah tentu jauh dari kota propinsi, saya hidup dengan adik-adik di kos-kosan, masalah yang dihadapi mahasiswa trutama kiriman dalam bentuk materi (uang semester, uang kos) terlambat, maka satu-satunya cara saya harus bekerja. 
Dari penjelasan di atas peneliti dapat merasakan betapa susahnya tinggal jauh dari orang tua, apalagi para mahasiswa banyak kebutuhan yang harus dipenuhi selain biaya kuliah kebutuhan akan makan yang juga harus terpenuhi serta betuhan lainya.

Selain itu para orang tua juga merasa terbantu dengan anaknya yang bekerja dalam hal ini anak hanya bekerja untuk memenuhi kebutuhanya selama masa kuliah. Sedangkan orang tua hanya melengkapi kebutuhan yang diperlukan anak ketika mengalami kekurangan terhadap apa yang diperlukan anak tersebut. Namun bukan berarti orang tua tidak mengontrol pergerakan anak ketika bekerja terhadap perkembangan kuliahnya, karena bagi orang tua pendidikanlah lebih penting walaupun tujuan akhir dari kuliah adalah mendapatkan pekerjaan yang layak dan mampu bertahan hidup di tengah arus gelobal yang semakin berkembang sehingga mereka mampu menciptakan pekerjaan terhadap dirinya dan untuk orang lain.

Mahasiswa pekerja berbeda dengan mahasiswa pada umumnya yang hanya melakukan aktivitas sehari-harinya sebatas tugas kuliah, mahasiswa yang kuliah sambil bekerja, harus membagi waktunya untuk kuliah dan pekerjaannya. Sistem kurikulum strata satu (S-1) yang dapat ditempuh dalam waktu empat tahun, menyebabkan jadwal kuliah menjadi padat. Bagi mahasiswa yang aktif organisasi tentu aktivitasnya menjadi lebih padat lagi. Jika mahasiswa tersebut juga bekerja, maka semakin banyak tuntutan tugas yang harus dipenuhi, baik tuntutan akademik, organisasi, pekerjaan, keluarga, dan teman. Menurut Robbins (1996) diacu dalam Bahiyah (2005) mengatakan bahwa adanya berbagai tugas yang mengkonfrontasikan seorang individu dengan suatu peluang, kendala (constrain) dan tuntutan (demand) yang berkaitan dengan apa yang diinginkan oleh individu tersebut dan hasilnya dipersepsikan sebagai tidak pasti dan penting maka berpeluang menyebabkan stress, demikian pula dengan kondisi mahasiswa yang kuliah sambil bekerja.

\section{Pembagian Waktu Kerja dan Kuliah}

Kuliah sambil bekerja di kalangan mahasiswa di Indonesia hingga saat ini belum banyak dilakukan. Salah satu penyebabnya adalah sangat sedikitnya lapangan pekerjaan yang tidak sesuai dengan kondisi mahasiswa dalam masalah waktu (Wahono 2004). Walaupun demikian, ada juga mahasiswa yang melakukannya dengan membagi waktunya secara ketat. 
Didalam proses kuliah dan kerja harus seimbang dalam menjalankanya, sehingga tidak ada pekerjaan yang tidak dijalankan untuk memenuhi kebutuhan antara mahasiswa dan para pemilik tokoh atau majikan. Dalam penelitian ini peneliti mendapatkan cukup baik para mahasiwa dalam membagi waktunya antara kerja dan kuliah, hal ini dapat dibuktikan dengan prestasi belajar yang mereka dapatkan dalam bangku perkuliahan dari masingmasing universitas yang ada di Maluku.

Selain itu peneliti mendapatkan keluhan dari majikan (pedagang), memang pada dasarnya para majikan (pedagang) tidak menerima mahasiswa untuk bekerja apalagi mereka yang kuliahnya pagi atau siang hari, karena dari mereka bekerja tentu prestasi mereka akan terhambat, terutama bagi mereka yang tidak bisah membagikan waktunya untuk bekerja dan kuliah, dan para pedagang akan merasa rugi jika mahasiswa bekerja karna waktu bekerja digunakan untuk pergi kuliah, apalagi mereka yang di gaji perbulan tentu kami akan merasa rugi. Namun demikian mereka yang datang adalah para saudara/i yang mau tinggal dengan kami sampai mereka selesai kuliah, walaupun mereka tidak dikasih gaji yang penting makananya diperhatikan setiap hari, bagi mereka itu sudah bersukur alhamdulilah apalagi hidup di daerah perkotaan.

\section{Prestasi Belajar yang Dihasilkan}

Prestasi adalah hasil yang telah dicapai seseorang dalam melakukan kegiatan. Gagne (1985:40) menyatakan bahwa prestasi belajar dibedakan menjadi lima aspek, yaitu: kemampuan intelektual, sterategi kognitif, informasi verbal, sikap dan keterampilan.

\section{Tabel 1. Standar Aturan IPK BAN PT}

\begin{tabular}{cl} 
Nilai & Standar Ketetapan IPK BAN PT \\
$\mathbf{4}$ & IPK $>3.00$ \\
$\mathbf{3}$ & $2.75<\mathrm{IPK} \leq 3.00$ \\
$\mathbf{2}$ & $2.50<\mathrm{IPK} \leq 2.75$ \\
$\mathbf{1}$ & $2.25<\mathrm{IPK} \leq 2.50$ \\
$\mathbf{0}$ & $2.00<\mathrm{IPK} \leq 2.25$ \\
\hline
\end{tabular}

(Anonim, 2010).

Dari tabel 1 pemerintah memiliki ketentuan tersendiri untuk mahasiswa dalam merai prestasi belajar ketika berda di perguruan tinggi. Hal ini tentu membuat para mahasiswa harus bekerja dan belajar yang keras untuk merai prestasi dengan standar nilai lebih dari 3.00, jika tidak mencapai ideks tersebut maka prosees mahasiswa di perguruan tinggi akan terasa lambat dan bahkan sampai pada drop out dari iniversitas tertentu jika kurang dari IPK 3.00 .

Pada tingkat perguruan tinggi mahasiswa adalah orang-orang yang sedang 
mengikuti pendidikan tentunya mempunyai harapan akan keberhasilan studi demi masa depannya. Sebagai salah satu tolak ukur keberhasilan mahasiswa adalah nilai yang diperolehnya adalah tinggi yang dihitung dengan nilai rata-rata disebut Indek Prestasi Kumulatif (IPK). Indeks prestasi kumulatif merupakan angka yang menunjukkan prestasi atau kemajuan belajar mahasiswa secara kumulatif mulai dari semester pertama sampai dengan semester paling akhir yang telah ditempuh (Nadziruddin; 2007).

Berbicara mengenai prstasi belajar La Udin Amimu (26 tahun alumni unpatti) mengatakan bahwa:Prestasi yang saya hasilkan selama masih kuliah dari semester I (satu) sampai dengan semester akhir VII (tujuh) sangatah baik dengan memperoleh Indeks Prestasi Kumulatif (IPK) $\geq 3.25$ dan tidak ada hambatan dalam proses akadmik di kampus.

Berbicara masalah prestasi tentu sangatlah baik, ketika La Udin Amimu (26 tahun pedagang asesori/pedagang HP) masih kuliah di Universitas Pattimura Ambon pada Fakultas Hukum (Alumni) dengan meperoleh Indeks Prestasi Kumulatif (IPK) 3.25 sampai dengan 3.75 dari awal kuliah sampai akhir. Beasiswa pernah di peroleh selama masih berada di bangku kuliah yaitu beasiswa Pengembangan Prestasi Akademik (PPA).
Menurut Siti Fatima Sujud (22 tahun/penjual jilbab) mengatakan bahwa:Prestasi yang saya peroleh di kampus sangat baik mulai dari awal kuliah semester satu sampai sekarang semester tujuh dengan indeks prestasi yaitu lebih dari 3.29, prestasi lain yang saya peroleh di kampus yaitu beasiwa PPA dari semester II (dua) sampai semester VII (tujuh).

Dari penjelasan lain mahasiswa pekerja di pasar yang bernama La Dafit Hasni (22 tahun/karyawan pekayan jadi) mengatakan bahwa:Prestasi belajar yang saya dapatkan pada semester I (satu) sangatlah bagus dengan memperoleh IPK 3.31, dan semester II (dua) yaitu 3.73, dalam proses kuliah yang terjadi pada semester satu dan semester dua berjalan dengan baik.

Adanya peningkatan prestasi belajar di kampus yang terjadi pada semester satu dan dua dengan memperoleh IPK 3.73. Hal ini menunjukan bahwa proses kuliah yang dialami oleh La Dafit Hasni (22 tahun) sangat baik dan serius terhadap pendidikan dan prestasi belajar yang dijalankanya di kampus maupun kuliah sambil kerja.

$$
\text { Menurut Hamirudin }
$$

tahun/penjual sticker) mahasiswa IAIN mengatakan bahwa:Prestasi yang saya peroleh sangat baik pada semester I (satu) dan semester II (sua) yaitu 3.50-3.86, 
prestasi lain yang saya peroleh antara lain mendapatkan beasiswa BBM, dan mengikut organisasi ekstra kampus.

Dari penjelasan Hamirudin (22 tahun/penjual sticker) mahasiswa IAIN ini menunjukan adanya prestasi belajar yang baik dalam proses akademik, selain mendapatkan indeks prestasi yang baik maupun juga mendapatkan beasiswa dan mengikuti organisasi diluar kempus.

Prestasi belajar dapat diukur melalui tes yang sering dikenal dengan tes prestasi belajar. Menurut Saifudin Anwar (2005 : 89) mengemukakan tentang tes prestasi belajar bila dilihat dari tujuannya yaitu mengungkap keberhasilan sesorang dalam belajar. Testing pada hakikatnya menggali informasi yang dapat digunakan sebagai dasar pengambilan keputusan.

Winkel (1996:226) mengemukakan bahwa prestasi belajar merupakan bukti keberhasilan yang telah dicapai oleh seseorang. Maka prestasi belajar merupakan hasil maksimum yang dicapai oleh seseorang setelah melaksanakan usaha-usaha belajar. Sedangkan menurut Arif Gunarso (1993:77) mengemukakan bahwa prestasi belajar adalah usaha maksimal yang dicapai oleh seseorang setelah melaksanakan usaha-usaha belajar.

\section{SIMPULAN}

Mahasiswa pekerja di Pasar Mardika Kota Ambon dalam membagi waktunya antara kerja dan kuliah sangatlah baik hal ini dapat dibuktikan dengan prestasi belajar yang mereka dapatkan selama masa perkuliahan, baik prestasi akademik maupun non akademik sehingga diapresiasi dengan berbagai beasiswa yang didapatkanya. Selain itu adanya tingkat kedisiplinan yang baik dalam pembagian waktu antara kerja dan kuliah serta rasa tanggung jawab yang dimiliki sebagai mahasiswa ketika bekerja di pasar.

\section{DAFTAR PUSTAKA}

Arif Gunarso. 1993. Bagaimana Bimbingan dan Penyaluhan Belajar di Sekolah, Surabaya: Usaha Nasional

Dalyono, M. 1996. Psikologi Pendidikan. Jakarta: Rineika Cipta

Ehrembergr, R. G. And R. S. Smith. 2003. Modern Labor Economic: Theorand Public Policy. Pearson Education Inc, New York City

Gagne R.M. 1985. The Condution of Learning Theory of Instrucion. New York: Rinehart

George Ritzer dan Douglas J.Goodman. Teori Sosiologi Modern (2007). Hlm. 121.

Teori Sosiologi Modern (2007). Hlm. 123.

Nadzirudin. 2007. Pengaruh Indeks Prestasi Kemulatif dan Persepsi Mahasiswa Akutansi Kota Medan Mengenai Beberapa Faktor Tertentu Terhadap Polihan Karir. Tesis Hj Retnawati Siregar pada Mahasiswa Univ. Sumatra Utara. Tidak diterbitkan 
Ningsih A.R. 2004. Mungkinkan Mahasiswa Kuliah Sambil Kerja?. [terhubung berkala]. http//www.pikiran-rakyat.com. [08 januari 2013].

Robbins, Stephen P. 1996. Perilaku Organisasi Edisi ke 7 (Jilid II). Jakarta: Prehallindo

Syamsi, Ibnu, S.U. 2000. Pengambilan Keputusan dan Sistem Informasi. Cetakan Kedua. Sinar Grafika Offset.

Wahono T. 2004. Kuliah sambil bekerja. [terhubung berkala]. http//www.pikiranrakyat. com. [08 januari 2013].

Winkel 1996. Oxford Advenced Learner's Distonary of Current English. Oxford University Press

\section{PEROFIL SINGKAT}

Penulis, La Basri lahir di dusun Tapinalu desa Luhu, kecamatan Seram Bagian Barat (SBB), pada tanggal 11 Maret 1990. Pada jenjang pendidkan tinggi penulis mengikuti studi pada Jurusan Sosiologi Fakultas Ilmu Sosial dan Ilmu Politik (FISIP) Universitas Pattimura Ambon yang diselesaikan pada tahun 2014. Selanjutnya penulis melanjutkan studi S2 Pascasarjana Sosiologi Universitas Pattimura Ambon selesai pada tahun 2017. Dan aktifitas sekarang yang dijalani sebagai Dosen tetap Universitas Muhammadiyah Sorong. 